\title{
ANALISIS RASIO KEUANGAN UNTUK MENEMUKAN BANK JANGKAR (STUDI PADA BANK UMUM SYARIAH DI INDONESIA)
}

\author{
Oleh: \\ Achmad Zainuri *) \\ Agus Sucipto ${ }^{* *}$
}

\begin{abstract}
This research based on API, anchor bank, and the growth of syariah commercial bank (BUS). This research aims to description BUS financial ratio with documentary technic in collecting data. This research use secondary data in form of financial report. Instrument analysis is banking financial ratios with time series analysis and cross sectional approach as tekhnis analysis.

The research shows that syariah commercial bank have potential to be an anchor bank, but PT. Bank Muamalat Indonesia have more potential according to his financial ratios.
\end{abstract}

Keywords: financial ratio, anchor bank, syariah commercial bank.

\section{PENDAHULUAN}

\section{Latar Belakang}

Sejak dikeluarkannya Arsitektur Perbankan Indonesia pada 9 januari 2004, banyak program yang telah dijalankan dan diterapkan. Aturan yang paling sering kita dengar adalah mengenai penguatan struktur permodalan perbankan nasional baik bank konvensional ataupun bank syariah. Memang API memberikan suatu harapan bagi perbankan Indonesia, namun tidak lupa membawa efek bagi beberapa bank yang ada. Dampak yang terlihat dari penguatan struktur modal perbankan dan bank jangkar adalah akan berkurangnya jumlah bank yang ada, atau bahkan terjadi merger antar bankbank yang kurang kuat modalnya.

Selain mengenai struktur permodalan, isu mengenai bank jangkar juga hangat dibicarakan selain karena kriterianya yang cukup berat, ada beberapa kriteria yang masih disangsikan oleh sebagian kalangan. Bank Jangkar adalah bank yang tidak hanya untuk menampung bank-bank kecil, atau konsolidator semata, tapi juga memiliki potensi untuk menjadi market leader di pasar domestik dan regional (InfoBank Outlook 2006:36). Adapun kriteria bank jangkar yang disebutkan bank indonesia adalah: $s a t u$, CAR minimal 12\%; dua, rasio modal inti 
minimal 6\%; tiga, ROA minimal 1,5\%; empat, pertumbuhan kredit minimal $22 \%$; lima, LDR minimal50\%; enam, NPL di bawah 5\%(Kompas, 2005:19).

Di Indonesia perkembangan perbankan syariah begitu pesat, hal ini dapat terlihat dari jumlah bank syariah baik yang berbentuk bank umum syariah, unit usaha syariah, dan bank perkreditan rakyat syariah. Namun, pangsa pasar perbankan syariah baru mencapai 1,3\% padahal penduduk muslim Indonesia sekitar 200 juta jiwa.

Suatu bank dikatakan maju atau berkembang apabila dapat mencapai atau melebihi target yang telah ditetapkan. Untuk melihat kemajuan tersebut dapat dilakukan dengan melihat laporan keuangannya yang selanjutnya dianalisis. Dalam menganalisis laporan keuangan dapat dilakukan dengan berbagai teknik, salah satunya dengan analisis rasio keuangan. Analisis rasio keuangan merupakan teknik analisis keuangan untuk mengetahui hubungan diantara pospos tertentu dalam neraca maupun laporan laba rugi baik secara individu maupun secara simultan.

Penelitian dengan tekhnik analisis rasio keuangan ini telah banyak dilakukan. Penelitian tentang bank syariah yang menggunakan tekhnik ini, menghasilkan kesimpulan bahwa bank syariah memiliki kinerja yang lebih baik. Seperti yang dilakukan oleh Daruli (2003) yang menyimpulkan bahwa Bank Muamalat Indonesia secara umum memiliki kinerja yang lebih baik dibandingkan dengan Bank Haga, Apriliyanti (2004) menyimpulkan bahwa PT. Bank Syariah Mandiri mampu menjaga tingkat likuiditas, profitabilitas, dan solvabilitasnya di atas standar yang ditetapkan.

Berdasarkan uraian yang telah dikemukakan di atas, dalam rangka menemukan bank jangkar berdasarkan rasio keuangannya, dalam tulisan ini berusaha untuk menemukan bank jangkar dengan membandingkan rasio keuangan BUS dengan kriteria bank jangkar dan membandingkan rasio keuangan BUS untuk mengetahui manakah yang lebih berpotensi untuk menjadi bankjangkar. 


\section{Rumusan Masalah}

Bagaimana rasio keuangan bank umum syariah, apakah sesuai dengan kriteria bankjangkar?

\section{Tujuan Penelitian}

Untuk mendeskripsikan rasio keuangan bank umum syariah dalam memenuhi kriteria bankjangkar.

\section{KAJIAN TEORI}

\section{Penelitian Terdahulu}

Hasil penelitian tentang struktur permodalan perbankan di Indonesia sesuai kriteria API, dilakukan oleh Djoko Retnadi (Info Bank: 2004) menyatakan bahwa di Indonesia belum ada bank internasional dengan modal 50 trilyun lebih. Bank dengan modal 10-50 trilyun atau bank nasional baru ada empat bank, bank dengan modal 100 miliar- 10 trilyun atau bank fokus berjumlah 82 bank, dan bank dengan modal di bawah 100 miliar atau bank dengan kegiatan terbatas berjumlah 48 bank.

Apriliyanti (2004), meneliti tentang perkembangan kinerja keuangan bank syariah dengan studi pada PT. Bank Syariah Mandiri. Dengan menggunakan rasio keuangan bank yaitu: rasio likuiditas, rasio profitabilitas, dan rasio solvabilitas. Hasil penelitian menunjukkan bahwa PT. Bank Syariah Mandiri mampu menjaga rasio likuiditas, rasio profitabilitas, dan rasio solvabilitas di atas standart yang ditetapkan.

Penelitian yang akan dilakukan oleh peneliti memiliki tidak jauh berbeda dengan penelitian-penelitian terdahulu. Persamaan tersebut dapat kita lihat pada alat analisis yang digunakan dan obyek penelitiannya. Namun penelitian ini juga memiliki perbedaan pada tujuan penelitian, teknik analisis yang digunakan yaitu dengan time series analisis dan cross sectional approach, serta jumlah bank yang diteliti. 
Beberapa rasio keuangan bank yang digunakan sebagai dasar pengukuran untuk menemukan bank jangkar diantaranya adalah rasio likuiditas, rasio permodalan, dan rasio profitabilitas.

Rasio permodalan dinilai dari besarnya financing to deposits ratio (FDR) dan besarnya non performing financing ratio (NPF), rasio permodalan dinilai dari tingkat kecukupan modal (capital adequacy ratio atau (CAR) dan rasio modal inti (RMI), Dan rasio profitabilitas dinilai dengan menggunakan rasio return on assets (ROA).

\section{Analisis Rasio Keuangan}

Analisis rasio adalah cara analisis dengan menggunakan perhitunganperhitungan perbandingan atas data kuantitatif yang ditunjukkan dalam neraca maupun laporan laba rugi(Kuswadi, 2004:187). Rasio menggambarkan suatu hubungan atau perimbangan (mathematical relationship) antara suatu jumlah tertentu dengan jumlah yang lain, dan dengan menggunakan alat analisis berupa rasio ini akan dapat menjelaskan atau memberi gambaran kepada penganalisis tentang baik atau buruknya keadaan atau posisi keuangan suatu perusahaan terutama jika angka ratio tersebut dibandingkan dengan angka rasio yang digunakan sebagai standart(Munawir, 1986:64).

Dalam neraca kita dapat melihat sejauh mana perkembangan modal suatu perusahaan. Dan dalam laporan rugi laba kita akan melihat kemajuan suatu perusahaan. Jadi analisis rasio dapat dilihat dari masing-masing laporan tersebut, atau perpaduan dari keduanya karena masing-masing dapat saling mendukung satu dengan lainnya. Dengan analisis rasio diharapkan nantinya dapat memberi gambaran tentang posisi keuangan perusahaan yang terbaru,jadi tidak salah kalau analisis ini dikatakan berorientasi ke depan.

Untuk memberikan gambaran posisi keuangan perusahaan, setiap penganalisis memiliki aspek yang berbeda untuk dianalisis. Seperti yang diungkapkan Husnan (1998:560) "...setiap analis keuangan bisa saja merumuskan rasio tertentu yang dianggap mencerminkan aspek tertentu. Karena itu pertanyaan pertama yang perlu dijawab adalah aspek-aspek apa yang akan 
dinilai. Pemilihan aspek-aspek yang akan dinilai perlu dikaitkan dengan tujuan analisis...". Dari pernyataan tersebut terlihat bahwa tidak ada batas minimal atau maksimal tentang aspek yang akan dianalisis. Yang menjadi patokan dari aspek yang akan dinilai adalah tujuan dari analisis itu sendiri.

\section{Jenis-Jenis Rasio Keuangan}

Secara umum rasio keuangan bank memiliki persamaan dengan rasio perusahaan. Tetapi untuk rasio bank secara umum menurut Deanto (2003:183) dapat dibagi dalam lima kategori:

a. Rasio Likuiditas: suatu lembaga keuangan atau bank dikatakan likuid jika bank yang bersangkutan sanggup melunasi utang-utangnya, membayar semua depositnya, serta dapat memenuhi permintaan kredit tanpa harus terjadi penangguhan.

Rasio likuiditas ini biasanya terdiri dari:

\section{Quick Ratio :}

\section{Cash Assets} Total Deposits

Rasio ini digunakan untuk mengukur kemampuan bank dalam membiayai kembali utangnya kepada nasabah yang menyimpan dananya dengan cash assets yang dimilikinya.

Investing Policy Ratio:

Total Deposits

Rasio ini merupakan kemampuan bank dalam membayar kembali kewajiban kepada para nasabah dengan mencairkan surat-surat berharga yang dipunyai bank.

\section{Banking Ratio:}

$$
\frac{\text { Total Loan }}{\text { Total Deposit }}
$$

Rasio ini merupakan kemampuan bank dalam membayar utangutangnya kepada nasabah yang menanamkan dananya, dengan menarik kredit-kredit yang telah diberikan kepada para debiturnya. 
Cash Ratio:

\begin{tabular}{c|} 
Cash Assets \\
Pinjaman yang harus segera dibayar
\end{tabular}

Rasio ini adalah kemampuan bank dalam membayar utang-utangnya yang telah jatuh tempo dengan cash assets yang dimilikinya.

Selain empat rasio di atas ada lagi rasio yang lain seperti:

Loan to Assets Ratio:

$\frac{\text { Total Loan }}{\text { Total Assets }}$

Rasio ini dipergunakan untuk mengukur kemampuan bank dalam memenuhi permintaan kredit melalui jaminan sejumlah aset yang dimiliki.

Investment to Portofolio Ratio:

\section{Marketable Securities Total Securities}

Rasio ini dipergunakan untuk mengukur tingkat likuiditas penanaman bank dalam surat berharga.

b. Rasio Profitabilitas: rasio ini digunakan untuk mengetahui kemampuan bank dalam menghasilkan laba selama periode tertentu. Rasio ini juga dapat digunakan untuk mengukur tingkat efektivitas manajemen dalam menjalankan operasionalnya.

Rasio Profitabilitas bank terdiri atas:

Gross Profit Margin:

$$
\frac{\text { (Operating Income - Operating Expense) }}{\text { Operating Income }}
$$

Rasio ini digunakan untuk mengetahui kemampuan bank dalam menghasilkan laba operasi melalui pendapatan operasi yang dihasilkan.

Net Profit Margin:

\begin{tabular}{|c|}
$\frac{\text { Net Income }}{\text { Operating Income }}$ \\
\hline
\end{tabular}

Dipergunakan untuk mengetahui kemampuan bank dalam menghasilkan laba bersih melalui pendapatan operasi. 
Return on Equity: $\quad \frac{\text { Net Income }}{\text { Equity }}$

Dipergunakan untuk mengetahui kemampuan bank dalam menghasilkan laba bersih melalui penggunaan modal sendiri.

Income to Total Assets:

Net Income Total Assets

Dipergunakan untuk mengetahui kemampuan bank dalam menghasilkan laba bersih melalui penggunaan sejumlah aktiva bank.

Gross Income to Total assets: $\frac{\text { Gross Income }}{\text { Total Assets }}$

Dipergunakan untuk mengetahui kemampuan bank dalam menghasilkan laba kotor melalui penggunaan sejumlah aset.

Retun on Investment (ROI):

$\frac{\text { Laba Bersih setelah Pajak }}{\text { Total Aktiva }}$

Rasio ini mengukur kemampuan bank dalam mengelola aktivanya untuk menghasilkan laba bersih setelah pajak. Selain rasio-rasio di atas untuk melihat rasio profitabilitas suatu bank masih ada rasio yang lain.

c. Rasio Solvabilitas: Untuk mengetahui kemampuan kecukupan modal bank dalam mendukung kegiatan bank secara efisien.

Untuk mengukur kemampuan permodalan ada beberapa analisis yang dapat digunakan, diantaranya:

Capital Adequacy Ratio (CAR): $\frac{\text { Modal }}{\text { ATMR }} \times 100 \%$ 
Dipergunakan untuk mengukur kecukupan modal guna menutupi kemungkinan kegagalan dalam pemberian kredit.

\section{Primary Ratio: $\quad \frac{\text { Equity Capital }}{\text { Total Assets }}$}

Rasio ini merupakan kemampuan permodalan suatu bank untuk menutup aktivanya akibat dari penurunan nilai yang diakibatkan oleh beberapa kerugian yang tidak terelakkan.

\section{Capital Ratio: $\quad \frac{\text { Equity Capital }}{\text { Total Loans }}$}

Rasio ini merupakan kemampuan permodalan bank dalam menutup kegagalan yang ada dalam proses permodalan kredit.

d. Rasio Resiko Usaha Bank: Untuk mengukur kemampuan bank dalam menyanggah resiko dari aktivitas operasi.

Untuk menganalisis jenis rasio ini, dapat digunakan beberapa analisis diantaranya:

\section{Credit Risk:}

\section{$\frac{\text { Bad Debt }}{\text { Total Loan }}$}

Dipergunakan untuk mengukur kemampuan bank dalam menyanggah resiko kegagalan pengembalian kredit oleh debitur.

\section{Liquidity Risk:}

$$
\frac{\text { Liquid Asset - Short Term Borrowing }}{\text { Total Deposit }}
$$

Dipergunakan untuk mengukur kemampuan bank dalam menyanggah resiko kemungkinan kegagalan memenuhi kewajiban kepada para deposan. 
Assets Risk:

$$
\begin{gathered}
\frac{\text { Equity }}{\text { Total Assets - (Cash-Securties })} \\
\text { (Cas }
\end{gathered}
$$

Dipergunakan untuk mengukur kemampuan bank dalam menyanggah resiko kegagalan pengembalian simpanan yang segera dibayarkan kepada debitur melalui jaminan modal sendiri.

Investment Risk:

Market Value of Securities Statement value of Securities

Dipergunakan untuk mengukur kemampuan bank dalam menyanggah resiko penurunan surat berharga.

e. Rasio Efisiensi Usaha Bank: Untuk mengetahui kinerja manajemen dalam menggunakan semua assets secara efisien.

Untuk menilai efisiensi dari kinerja manajemen dapat diukur dengan rasio di bawah ini:

Leverage Multiplier:

$\frac{\text { Total Assets }}{\text { Total Capital }}$

Dipergunakan untuk mengetahui kemampuan manajemen bank dalam mengelola aktiva yang dimiliki mengingat biaya yang dikeluarkan dalam mengelola aktiva.

Assets Utilization:

Operation Income + non Operation Income Total Assets

Dipergunakan untuk mengukur kemampuan manajemen bank dalam memanfaatkan aktiva yang dimiliki guna menghasilkan laba operasi dan laba non operasi.

Cost of Fund: $\frac{\text { Interest Paid }}{\text { Total Fund }}$ 
Dipergunakan untuk mengetahui kemampuan bank membayar biaya bunga dibanding rata-rata dana yang dimiliki.

Cost of Money:

$$
\frac{\text { Cost of Fund }+ \text { Overhead Expense }}{\text { Total Fund }}
$$

Dipergunakan untuk mengetahui berapa besar rata-rata keseluruhan biaya yang dikeluarkan bank dalam penghimpunan dana.

\section{Cost of Loanable Fund:}

$$
\text { Total Fund - Unloanable Fund }
$$

Dipergunakan untuk mengetahui biaya variable yang digunakan untuk memperoleh loanable fund.

\section{Rasio Keuangan Bank Syariah}

Rasio keuangan bank syariah sebenarnya tidak jauh berbeda dengan rasio keuangan bank konvensional. Rasio keuangan bank syariah umumnya juga terdiri dari lima kategori seperti rasio likuiditas, rasio profitabilitas, rasio solvabilitas, rasio resiko usaha bank, dan rasio efisiensi usaha bank.

Yang menjadi perbedaan adalah istilah yang digunakan. Ali menyatakan “...singkatnya belum murni syariah. Kemudian dari segi istilah sebenarnya hanya perbedaan istilah saja. Contohnya NPL (Non Performing Loan). NPL itu sebuah istilah yang digunakan di bank konvensional sedangkan di bank syariah namanya diganti NPF (Non Performing Financing) pembiayaan yang bermasalah jadi bukan kredit namanya. Jadi, hanya perbedaan istilah dan simbol-simbolnya diganti" (Ali, 2006). Jadi dalam hal rasio keuangan baik bank syariah maupun bank konvensional tidak benar-benar berbeda, kecuali pada isthilah yang digunakan.

Jika dilihat dari aspek rasio keuangan tidak jauh berbeda memang antara bank syariah dengan bank konvensional, namun jika kita telusuri lebih dalam, banyak aspek yang sangat membedakan keduanya. Pada Sertifikat Wadi'ah Bank Indonesia (SWBI) misalnya, berbeda dengan Sertifikat Bank 
Indonesia (SBI) sekalipun keduanya sama-sama memperoleh keuntungan dari BI. SWBI menggunakan akad wadi'ah yang memperoleh bonus dari BI, sedangkan SBI memperoleh bunga sesuai ketentuan BI.

Hal ini menjadi suatu argumen bahwa bank syariah bekerja berdasarkan syariah. Sekalipun ada pendapat yang menyatakan bahwa keuntungan yang diberikan BI adalah riba' maka bonus yang diberikan BI kepada bank syariah adalah haram. Tentunya bank syariah akan memilih bank sentral dengan prinsip syariah, namun karena belum seperti itu maka bank syariah mengikuti aturan yang ada. Yang menjadi perbedaan adalah sudut pandang seseorang, jika seseorang menilai bonus yang diberikan BI adalah riba' maka bank syariah selamanya tidak akan murni syariah jika BI tidak berprinsip syariah.

\section{Pengertian Bank Umum Syariah}

Dalam Pasal 1 UU No. 10 tahun 1998 dijelaskan bahwa bank adalah badan usaha yang menghimpun dana dari masyarakat dalam bentuk simpanan dan menyalurkannya kepada masyarakat dalam bentuk kredit dan/ atau bentuk-bentuk lainnya dalam rangka meningkatkan taraf hidup rakyat banyak. Sedangkan bank umum diartikan sebagai bank yang melaksanakan kegiatan usaha secara konvensional dan/ atau berdasarkan prinsip syariah yang dalam kegiatannya memberikan jasa dalam lalu lintas pembayaran(Abdullah, 2004:162).

Bank syariah merupakan lembaga intermediasi dan penyedia jasa keuangan yang bekerja berdasarkan etika dan sistem nilai Islam, khususnya yang bebas dari bunga ( $r i b a)$, bebas dari kegiatan spekulatif yang non-produktif seperti perjudian (maysir), bebas dari hal-hal yang tidak jelas dan meragukan (gharar), berprinsip keadilan, dan hanya membiayai kegiatan usaha yang halal(Ascarya dan Yumanita, 2005:4).

\section{Peran Bank Syariah}

Melihat pada pengertian bank, kita dapati dua peranan bank yang sangat mendasar yaitu sebagai financial intermediate maupun institute of economic 
development(Abdullah, 2004:17). Karena dua peran dasar tersebut maka ada sebutan yang mengatakan bank sebagai agent of trust, sebagai suatu badan usaha yang sarat dengan kepercayaan dari nasabahnya ataupun sebaliknya.

Adapun peranan bank syariah tidak jauh berbeda dengan peran bank pada umumnya. Bank Syariah mempunyai dua peran utama, yaitu sebagai badan usaha (tamwil) dan badan sosial (maal). Secara singkat peran bank syariah dapat kita lihat dari gambar berikut ini:

\section{Gambar 1}

Peran Bank Syariah

\begin{tabular}{|c|c|c|c|c|}
\hline & & TAMWIL & & MAAL \\
\hline $\begin{array}{l}\text { ज } \\
0 \\
z \\
2\end{array}$ & $\begin{array}{l}\text { Manager } \\
\text { Investasi }\end{array}$ & Investor & $\begin{array}{c}\text { Jasa } \\
\text { Perbankan }\end{array}$ & Sosial \\
\hline & $\begin{array}{l}\text { Penghimpunan } \\
\text { Dana }\end{array}$ & $\begin{array}{l}\text { Penyaluran } \\
\text { Dana }\end{array}$ & Jasa keuangan & Dana kebajikan \\
\hline 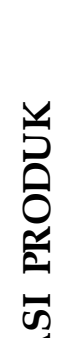 & $\begin{array}{l}\text { Prinsip wadiah } \\
\text { yad dhamanah: } \\
\text { giro, tabungan }\end{array}$ & $\begin{array}{l}\text { Pola bagi hasil: } \\
\text { mudharabah, } \\
\text { musyarakah, dll. }\end{array}$ & $\begin{array}{l}\text { wakalah, } \\
\text { kafalah, } \\
\text { hiwalah, ujr, } \\
\text { sharf, qard, } \\
\text { rahn, dll. }\end{array}$ & $\begin{array}{l}\text { Penghimpunan dan } \\
\text { penyaluran zis, serta } \\
\text { penyaluran qardhul } \\
\text { hasan }\end{array}$ \\
\hline 当 & $\begin{array}{l}\text { Prinsip } \\
\text { mudharabah: } \\
\text { tabungan, } \\
\text { deposito/investa } \\
\text { si, obligasi. }\end{array}$ & $\begin{array}{l}\text { Pola jual beli: } \\
\text { murabahah, } \\
\text { salam,isthisna', } \\
\text { dll }\end{array}$ & $\begin{array}{l}\text { Jasa Non } \\
\text { Keuangan: } \\
\text { Wadi'ah yad } \\
\text { Amanah. }\end{array}$ & \\
\hline
\end{tabular}




\begin{tabular}{|l|l|l|l|l|}
\hline obligasi. & Pola sewa: & Jasa \\
& ijarah, ijarah wa & keagenan: \\
iqtina'. & $\begin{array}{l}\text { mudharabah, } \\
\text { muqayyadah. }\end{array}$ & \\
\hline
\end{tabular}

Sumber: Ascarya dan Diana Yumanita. Bank Syariah: Gambaran Umum, (Jakarta, Pusat Pendidikan dan Studi Kebanksentralan, 2005)

Namun Hidayat (1999:4) menyatakan setidaknya ada empat peran perbankan Islam yaitu:

a. Peran aqidah: intinya dari segi aqidah perbankan Islam menjadi perbankan yang berorientasi pada pendidikan yang mendidik para pelaku perbankan untuk konsisten pada pemikiran perbankan Islam dan etika-etika Islam, mendidik para deposan untuk membuat perencanaan bagi diri mereka sendiri, bagi keluarganya dan menghilangkan nilai-nilai negatif pada diri mereka. Sebagaimana perbankan mendidik pelakunya dalam hal mendapatkan keuntungan dengan kejujuran, kesungguhan, dan ketekunan dalam bekerja.

b. Peran ekonomi: perbankan Islam dapat pula menjadi perbankan yang berorientasi pada bisnis dan keuntungan dengan berusaha dalam kegiatan bisnis perbankan untuk mendapatkan keuntungan, namun pelaku perbankan terlebih dahulu harus membersihkan kegiatan bisnis dari riba', penipuan, perjudian, penganiayaan, dan yang lainnya, agar benar-benar mendapatkan keuntungan yang halal.

c Peran sosial: perbankan Islam dapat menjadi perbankan yang berorientasi sosial, yang berusaha untuk memberikan jaminan sosial di balik penunaian zakat maal, mengelola zakat pelaku perbankan sesuai ketentuan, dan memberikan pembiayaan lunak seperti bantuan material dan bantuan sosial.

d Peran pertumbuhan: perbankan Islam untuk menjadi perbankan yang berorientasi pertumbuhan yang menopang sendi-sendi pertumbuhan, baik secara langsung atau dengan kemitraan atau dengan saling memberikan 
keuntungan dengan memprioritaskan kebutuhan masyarakat dimulai dari kebutuhan primer, kebutuhan sekunder, kemudian kebutuhan tersier.

\section{Pengertian dan Kriteria Bank Jangkar}

Bank jangkar adalah bank yang tidak hanya untuk menampung bankbank kecil, atau konsolidator semata, tapi juga memiliki potensi untuk menjadi market leader di pasar domestik dan regional (InfoBank Outlook 2006:36). Adapun kriteria bank jangkar, sebagaimana disebutkan bank indonesia pada booklet perbankan indonesia (2006:40) yaitu:

a. Bank memiliki kapasitas untuk tumbuh dan berkembang dengan baik, didukung permodalan yang kuat dan stabil serta memiliki kemampuan mengabsorsi resiko dan mendukung kegiatan usaha. Hal ini tercermin dari minimum CAR 12\% dan rasio modal inti (tier 1)/ ATMR Minimum $6 \%$.

b. Bank juga memiliki kemampuan untuk tumbuh secara berkesinambungan yang tercermin dari profitabilitas yang baik. Hal ini tercermin dari rasio Return On Asset (ROA) minimal 1,5\%.

c. Bank berperan dalam mendukung fungsi intermediasi perbankan guna mendorong pembangunan ekonomi nasional yang tercermin dari pertumbuhan ekspansi kredit sesuai dengan prinsip kehati-hatian. Hal ini tercermin dari pertumbuhan ekspansi kredit secara riil minimum 22\% pertahun atau Loan to Deposit Ratio minimum 50\% dan rasio Non Performing Loan di bawah 5\% (net).

d. Bank telah menjadi perusahaan terbuka atau memiliki rencana untuk menjadi perusahaan terbuka dalam waktu dekat.

e. Bank memiliki kemampuan dan kapasitas untuk menjadi konsolidator dengan tetap memenuhi kriteria sebagai bank kinerja baik. 
Adapun bank kinerja baik itu sendiri ialah bank-bank yang memenuhi kriteria selama 3 tahun terakhir sebagai berikut:

a. Memiliki modal inti lebih besar dari 100 miliar

b. Memiliki tingkat kesehatan secara keseluruhan tergolong sehat (sekurang-kurangnya peringkat komposit 2) dengan faktor manajemen tergolong baik.

c. Memiliki rasio kewajiban pemenuhan modal minimum (CAR) sebesar $10 \%$

d. Memiliki tata kelola (governance) dengan rating yang baik

e. Status bank kinerja baik tersebut nantinya akan terus dievaluasi oleh bank indonesia secara berkala, dan nantinya dapat berpotensi untuk menjadi bank jangkar.

\section{METODE PENELITIAN}

\section{Lokasi Penelitian}

Penelitian ini dilakukan di Perpustakaan Bank Indonesia Cabang Malang dengan alamat: Jl. Kawi No. 17 Telp. (0341) 357177 Malang.

\section{Jenis penelitian}

Jenis penelitian yang digunakan adalah penelitian deskriptif. Karena penelitian ini bertujuan untuk menguji aplikasi teori pada keadaan tertentu.

\section{Data dan Sumber Data}

Dalam penelitian ini data yang digunakan adalah laporan keuangan publikasi tahunan dan bulanan meliputi Neraca, Laporan Laba Rugi, Kualitas Aktiva Produktif, dan Kewajiban Penyediaan Modal Minimum selama 3 (tiga) periode yaitu antara tahun 2004 s/d 2006. Data diperoleh dari Direktori Perbankan Indonesia 2005, website Bank syariah Mandiri yaitu www.syariahmandiri.co.id, website Bank Indonesia yaitu www.bi.go.id. dan website Bank Muamalat yaitu www. Dokumen-dokumen tersebut didapat dari pihak lain, bukan oleh peneliti sendiri, artinya didapat secara tidak langsung. 
Karena tidak diperoleh secara langsung, jadi data pada penelitian ini merupakan data sekunder.

\section{Metode Pengumpulan Data}

Pada penelitian ini metode pengumpulan data menggunakan metode dokumentasi, yaitu mencari data mengenai hal-hal atau variable yang berupa catatan, transkrip, buku, surat kabar, majalah, prasasti, notulen rapat, lengger, agenda dan sebagainya(Arikunto, 2002:206). Metode ini dilakukan berkaitan dengan obyek dan subyek penelitian melalui pencatatan dokumen-dokumen Bank Umum Syariah dan bahan kepustakaan yang terkait dengan penelitian ini.

\section{Analisis Data}

Adapun tahap-tahap dalam analisis data adalah sebagai berikut:

1. Mengumpulkan data keuangan PT. Bank Muamalat Indonesia (BMI), PT. Bank Syariah Mandiri (BSM), PT. Bank Syariah Mega Indonesia (BSMI). yang berupa neraca, laporan rugi laba, kualitas aktiva produktif, dan kewajiban penyediaan modal minimum pada periode $2004 \mathrm{~s} / \mathrm{d} 2006$.

2. Melakukan perhitungan rasio keuangan terhadap neraca, laporan laba rugi, kualitas aktiva produktif, dan kewajiban penyediaan modal minimum pada periode 2004 s/d 2006. Adapun rasio keuangan yang digunakan dalam penelitian ini sebagaimana rasio untuk kriteria bank jangkar yang diumumkan oleh bank indonesia.

3. Melakukan analisis atas hasil perhitungan rasio keuangan dengan metode time series analisis dan metode cross sectional approach dengan pendekatan deskriptif.

4. Menyajikan hasil dari analisis rasio keuangan PT. Bank Muamalat Indonesia (BMI), PT. Bank Syariah Mandiri (BSM), PT. Bank Syariah Mega Indonesia (BSMI). Sesuai dengan periode tahun yang diteliti.

5. Menganalisis hasil rasio ketiga Bank yang diteliti, manakah yang lebih berpeluang untuk menjadi bankjangkar. 


\section{HASIL PENELITIAN DAN PEMBAHASAN}

\section{PT. Bank Muamalat Indonesia (BMI)}

\section{Faktor Likuiditas}

Likuiditas PT. BMI mampu dijaga dengan baik selama tiga periode penelitian. Hal tersebut terlihat dari financing to deposits ratio (FDR) dan rasio non performing financing (NPF) yang memenuhi kriteria FDR dan NPF yang ditetapkan untuk bankjangkar.

Tabel. 1. Perkembangan FDR dan Rasio NPF PT. BMI

Tahun 2004 s/d Tahun 2006 (Dalam Jutaan Rupiah)

\begin{tabular}{|l|l|r|r|r|}
\hline No. & Komponen & $\mathbf{2 0 0 4}$ & \multicolumn{1}{c|}{$\mathbf{2 0 0 5}$} & \multicolumn{1}{c|}{$\mathbf{2 0 0 6}$} \\
\hline 1 & Dana yang Diterima & 4.676 .599 & 6.836 .589 & 7.783 .048 \\
\hline 2 & Pembiayaan yang disalurkan & 4.182 .224 & 6.108 .157 & 6.628 .087 \\
\hline 3 & $\begin{array}{l}\text { Pembiayaan Bermasalah (KL, D, } \\
\text { M) }\end{array}$ & 123.435 & 165.088 & 381.598 \\
\hline 4 & FDR \% (2:1) & 89,43 & 89,36 & 85,16 \\
\hline 5 & NPF \% (3:2) & 2,95 & 2,70 & 5,76 \\
\hline
\end{tabular}

Ket: KL: Kulang Lancar, D: Diragukan, M: Macet.

Sumber: Direktori Perbankan Indonesia 2005 - Vol. 7, September 2006 dan http://www.bi.go.id, diolah.

Dari tabel 1, terlihat bahwa selama tiga tahun FDR PT. BMI masih di atas kriteria FDR bank jangkar (Min. 50\%) dan rasio NPF PT. BMI masih di bawah kriteria rasio NPF bank jangkar (Maks. 5\%). Sekalipun rasio NPF PT. BMI di tahun 2006 naik, namun itu masih nilai rasio NPF gross, jika diukur rasio NPF netnya maka tidak melebihi $5 \%$.

Selama tiga tahun FDR PT. BMI mengalami penurunan, hal ini tidak lepas dari tidak sebandingnya antara peningkatan dana yang diterima dengan pembiayaan yang disalurkan. Diketahui banwa pembiayaan PT. BMI selalu mengalami peningkatan, pada tahun 2005 pembiayaan meningkat 46\% dari 
tahun 2004, sedangkan pada tahun 2006 hanya sedikit meningkat yaitu sebesar 8,51\% dari tahun 2005. Penurunan FDR di tahun 2006 tidak lepas dari kondisi ekonomi yang terjadi yang berdampak pada penyaluran pembiayaan PT. BMI yang hanya naik $8,51 \%$.

Pada rasio NPF, PT. BMI mampu menjaganya di bawah kriterio rasio NPF bank jangkar. Adapun NPF yang tinggi di tahun 2006 adalah sutau tanda bahwa terjadi peningkatan debitur bermasalah di PT. BMI. Debitur bermasalah dapat ditanggulangi dengan cara mengetahui debitur (nasabah) lebih baik lagi dan memberi pendidikan kepada mereka mengingat bank Islam memiliki peran aqidah.

\section{Faktor Solvabilitas}

Solvabilitas PT. BMI mampu dijaga dengan baik selama tiga periode penelitian, hal ini dibuktikan dari capital adequacy ratio (CAR) dan rasio modal inti (RMI) yang selalu berada di atas kriteria CAR dan RMI untuk bank jangkar (Min 12\% dan 6\%). Dengan melihat rasio solvabilitas kita dapat mengatahui kemampuan kecukupan modal PT. BMI dalam mendukung kegiatannya secara efisien.

Tabel. 2. Perkembangan CAR dan RMI PT. BMI Tahun 2004 s/d Tahun 2006 (Dalam Jutaan Rupiah)

\begin{tabular}{|l|l|r|r|r|}
\hline No. & Komponen & \multicolumn{1}{c|}{$\mathbf{2 0 0 4}$} & \multicolumn{1}{c|}{$\mathbf{2 0 0 5}$} & \multicolumn{1}{c|}{$\mathbf{2 0 0 6}$} \\
\hline 1 & Modal Inti & 314.937 & 705.641 & 731.159 \\
\hline 2 & Modal Pelengkap & 198.068 & 260.963 & 204.709 \\
\hline 3 & $\begin{array}{l}\text { Jumlah Modal } \\
(1+2)\end{array}$ & 513.005 & 966.604 & 935.868 \\
\hline 4 & Penyertaan & $(6.677)$ & $(6.677)$ & $(6.677)$ \\
\hline 5 & Total Modal (3-4) & 506.328 & 959.927 & 929.191 \\
\hline 6 & ATMR & 4.159 .840 & 5.876 .672 & 6.530 .364 \\
\hline 7 & CAR \% (5:6) & 12,17 & 16,33 & 14,29 \\
\hline 8 & RMI \% (1:6) & 7,57 & 12 & 11,20 \\
\hline
\end{tabular}

Sumber: Direktori Perbankan Indonesia 2005 - Vol. 7, September 2006 dan http://www.bi.go.id, diolah. 
Dari tabel 2, terlihat bahwa CAR dan RMI PT. BMI selama tiga periode penelitian berada di atas kriteria CAR dan RMI bank jangkar. Untuk CAR, PT. BMI mampu menjaganya di atas $12 \%$ selama tiga tahun. Sedangkan untuk RMI, PT. BMI mampu mencapai hampir dua kali dari nilai minimal RMI bank jangkar.

Selama tiga periode penelitian CAR PT. BMI mengalami peningkatan dan penurunan. Pada tahun 2004 sebesar 12,17\% lalu meningkat menjadi 16,33\% di tahun 2005, lalu turun menjadi 14,29\% di tahun 2006. Fluktuasi tersebut dipicu oleh perubahan pada struktur modal dan peningkatan nilai aktiva tertimbang menurut resiko (ATMR). Pada tahun 2005 terjadi penerbitan right issue sebesar 200 milyar rupiah yang merubah struktur modal PT. BMI.

Senada dengan CAR, RMI PT. BMI juga mengalami peningkatan dan penurunan. Pada tahun 2004 sebesar 7,57\%, lalu meningkat menjadi 12\% di tahun 2005, lalu turun menjadi $11,20 \%$ di tahun 2006. meningkatnya RMI di tahun 2005 lebih disebabkan tidak sebandingnya perubahan modal inti dengan perubahan ATMR.

\section{Faktor Profitabilitas}

Profitabilitas PT. BMI mampu terjaga dengan baik, hal ini terlihat dari rasio return on assets (ROA). Tapi pada tahun 2004 rasio ROA PT. BMI $(1,43 \%)$ sedikit berada di bawah kriteria rasio ROA bank jangkar (Min. 1,5\%). Dengan menghitung profitabilitas PT. BMI, diharapkan dapat diketahui kemampuan PT. BMI dalam menghasilkan laba.

Tabel. 3. Perkembangan Rasio ROA PT. BMI Tahun 2004 s/d Tahun 2006 (Dalam Jutaan Rupiah)

\begin{tabular}{|l|l|r|r|r|}
\hline No. & Komponen & $\mathbf{2 0 0 4}$ & $\mathbf{2 0 0 5}$ & $\mathbf{2 0 0 6}$ \\
\hline 1 & $\begin{array}{l}\text { Laba Sebelum } \\
\text { Pajak }\end{array}$ & 74.370 & 156.254 & 161.473 \\
\hline 2 & Total Aktiva & 5.209 .804 & 7.427 .047 & 8.370 .595 \\
\hline 3 & ROA \% (1:2) & 1,43 & 2.10 & 1.93 \\
\hline
\end{tabular}

Sumber: Direktori Perbankan Indonesia 2005 - Vol. 7, September 2006 dan http://www.bi.go.id, diolah. 
Dari tabel 3, terlihat bahwa terjadi peningkatan dan penurunan pada rasio ROA PT. BMI. Fluktuasi nilai ROA di atas terjadi karena peningkatan laba sebelum pajak pada tahun 2005 sebesar 110,10\% , sedangkan peningkatan total aktiva hanya sebesar 42,56\%. Pada tahun 2006 nilai rasio ROA yang turun adalah hasil dari tidak sebandingnya antara peningkatan laba sebelum pajak (3,34\% dari tahun 2005), sedangkan peningkatan total aktiva sebesar 12,70\% dari tahun 2005. Namun demikian, melihat perkembangan rasio ROAnya, PT. BMI berpeluang menjadi bankjangkar.

\section{PT. Bank Syariah Mandiri (BSM)}

\section{Faktor Likuiditas}

Likuiditas PT. BSM mampu dijaga dengan baik selama tiga periode penelitian. Hal tersebut terlihat dari financing to deposits ratio (FDR) dan rasio non performing financing (NPF) yang memenuhi kriteria bank jangkar (Min. 50\% dan Maks. 5\%). Dengan melihat rasio likuiditas, kita dapat mengetahui kemampuan PT. BSM dalam menyelesaikan kewajiban jangka pendeknya.

Tabel. 4. Perkembangan FDR dan Rasio NPF PT. BSM Tahun 2004 s/d Tahun 2006 (Dalam Jutaan Rupiah)

\begin{tabular}{|l|l|r|r|r|}
\hline No. & Komponen & $\mathbf{2 0 0 4}$ & \multicolumn{1}{c|}{$\mathbf{2 0 0 5}$} & \multicolumn{1}{c|}{$\mathbf{2 0 0 6}$} \\
\hline 1 & Dana yang Diterima & 6.421 .695 & 7.783 .149 & 8.914 .514 \\
\hline 2 & Pembiayaan yang disalurkan & 5.295 .655 & 5.847 .598 & 7.414 .757 \\
\hline 3 & $\begin{array}{l}\text { Pembiayaan Bermasalah (KL, D, } \\
\text { M) }\end{array}$ & 128.021 & 204.880 & 514.754 \\
\hline 4 & FDR \% (2:1) & 82,46 & 75,13 & 83,18 \\
\hline 5 & NPF \% (3:2) & 2,42 & 3,5 & 6,94 \\
\hline
\end{tabular}

Ket: KL: Kulang Lancar, D: Diragukan, M: Macet.

Sumber: www.syariahmandiri.co.id dan www.bi.go.id, diolah.

Dari tabel 4, terlihat bahwa FDR PT. BSM berada di atas kriteria FDR bank jangkar. Dan rasio NPF net yang berada di bawah kriteria rasio NPF bank jangkar, sekalipun demikian rasio NPF gross berada di atasnya $(6,94 \%)$.

Selama tiga peride FDR PT. BSM mengalami fluktuasi, hal ini tidak lepas dari tidak sebandingnya antara peningkatan dana yang diterima dengan 
peningkatan pembiayaan yang disalurkan. Diketahui pembiayaan PT. BSM selalu mengalami peningkatan. Pada tahun 2005 peningkatan pembiayaan sebesar 10,42\% dari tahun 2004 dan meningkat lagi pada tahun 2006 sebesar 26,8\% dari tahun 2005. penurunan FDR di tahun 2005 tidak lepas dari peningkatan dana yang diterima oleh PT. BSM sebesar 21,2\%, jadi peningkatan dana yang diterima lebih besar daripada pembiayaan yang disalurkan. Sedangkan peningkatan FDR di tahun 2006 adalah hasil dari pembiayaan yang berhasil dilakukan, dimana dana yang diterima hanya meningkat sebesar $14,54 \%$.

Namun keberhasilan pada FDR tidak diikuti keberhasilan dalam mengendalikan pembiayaan bermasalahnya. Dari tabel 4, terlihat perkembangan rasio NPF PT. BSM selalu mengalami peningkatan, puncaknya pada tahun 2006 rasio NPF PT. BSM sebesar 6,94\% (gross), namun setelah dihitung rasio NPF (net) tidak melampaui kriteria rasio NPF bank jangkar. Akan tetapi jika rasio NPF Pt. BSM terus meningkat maka peluang untuk menjadi bank jangkar akan lebih kecil. Untuk menjaga supaya rasio NPFnya tidak terus meningkat PT. BSM harus mengenali nasabahnya (debitur) lebih baik lagi, bahkan kalau perlu mendidik mereka untuk menjadi nasabah yang lebih baik.

\section{Faktor Solvabilitas}

Solvabilitas PT. BSM mampu dijaga dengan baik selama tiga periode penelitian, hal ini terlihat dari capiatal adequacy ratio (CAR) dan rasio modal inti (RMI) yang terus mengalami peningkatan tiap tahunnya. CAR PT. BSM baru bisa mencapai kriteria CAR bank jangkar (Min. 12\%) pada tahun 2006, sedangkan RMI mampu dijaga diatas kriteria RMI bank jangkar (Min. 6\%) selama tiga periode penelitian. Dengan melihat rasio solvabilitas kita dapat mengetahui kemampuan kecukupan modal PT. BSM dalam mendukung kegiatannya secara efisien. 
Tabel. 5. Perkembangan CAR dan RMI PT. BSM

Tahun 2004 s/d Tahun 2006 (Dalam Jutaan Rupiah)

\begin{tabular}{|l|l|r|r|r|}
\hline No. & Komponen & \multicolumn{1}{c|}{$\mathbf{2 0 0 4}$} & \multicolumn{1}{c|}{$\mathbf{2 0 0 5}$} & \multicolumn{1}{c|}{$\mathbf{2 0 0 6}$} \\
\hline 1 & Modal Inti & 493.514 & 581.438 & 655.377 \\
\hline 2 & Modal Pelengkap & 89.946 & 91.323 & 104.287 \\
\hline 3 & $\begin{array}{l}\text { Jumlah Modal } \\
(1+2)\end{array}$ & 583.460 & 672.761 & 759.664 \\
\hline 4 & Penyertaan & - & - & - \\
\hline 5 & Total Modal (3-4) & 583.460 & 759.664 & 759.664 \\
\hline 6 & ATMR & 5.519 .152 & 5.665 .285 & 6.046 .224 \\
\hline 7 & CAR \% (5:6) & 10,57 & 11,87 & 12,56 \\
\hline 8 & RMI \% (1:6) & 8,94 & 10,26 & 10,84 \\
\hline
\end{tabular}

Sumber: www.syariahmandiri.co.id dan www.bi.go.id, diolah.

Dari tabel 5, terlihat bahwa CAR dan RMI PT. BSM selama tiga periode selalu mengalami peningkatan. Adapun untuk kriteria CAR bank jangkar baru mencapainya di tahun 2006, sedangkan RMI PT. BSM mampu berada di atas kriteria RMI bank jangkar selama tiga periode.

Melihat perkembangan CAR PT. BSM, hal ini menunjukkan bahwa PT. BSM mampu menjaga kecukupan modalnya. Peningkatan tersebut terjadi karena peningkatan total modal lebih besar daripada peningkatan aktiva tertimbang menurut resiko (ATMR). Namun pada CAR, PT. BSM perlu mempertimbangkan untuk menambah modalnya yang dapat dilakuan melalui penyertaan atau dengan menambah modal pelengkap.

Untuk RMI, PT. BSM mampu menjaga dengan baik. Peningkatan yang dicapai selama tiga periode tidak lepas dari besarnya modal inti yang dimiliki oleh PT. BSM. Jika kita perhatikan terlihat bahwa modal inti PT. BSM memiliki andil yang lebih besar terhadap peningkatan CAR dan RMI yang berhasil dicapai. 


\section{Faktor Profitabilitas}

Profitabilitas PT. BSM menunjukkan penurunan selama tiga periode penelitian, bahkan berada di bawah kriteria rasio return on assets (ROA) bank jangkar di tahun 2006. jika penurunan rasio ROA ini berlanjut maka peluang PT. BSM akan lebih kecil untuk menjadi bank jangkar. Dengan menghitung profitabilitas PT. BSM, diharapkan dapat diketahui kemampuan PT. BSM dalam menghasilkan laba.

Tabel. 6. Perkembangan Rasio ROA PT. BSM Tahun 2004 s/d Tahun 2006 (Dalam Jutaan Rupiah)

\begin{tabular}{|l|l|r|r|r|}
\hline No. & Komponen & $\mathbf{2 0 0 4}$ & $\mathbf{2 0 0 5}$ & \multicolumn{1}{c|}{$\mathbf{2 0 0 6}$} \\
\hline 1 & $\begin{array}{l}\text { Laba Sebelum } \\
\text { Pajak }\end{array}$ & 150.421 & 136.712 & 95.237 \\
\hline 2 & Total Aktiva & 6.869 .949 & 8.272 .965 & 9.554 .967 \\
\hline 3 & ROA \% (1:2) & 2,19 & 1,65 & 1 \\
\hline
\end{tabular}

Sumber: www.syariahmandiri.co.id, diolah

Dari tabel 6, terlihat bahwa terjadi penurunan rasio ROA PT. BSM selama tiga periode penelitian. Penurunan ini adalah akibat dari turunnya laba sebelum pajak yang dihasilkan oleh PT. BSM, sedangkan total aktiva PT. BSM terus mengalami peningkatan tiap tahunnya.

\section{PT. Bank Syariah Mega Indonesia (BSMI)}

\section{Faktor Likuiditas}

Likuiditas PT. BSMI mampu dijaga dengan baik (di atas 50\%) selama tiga periode penelitian, sekalipun masih menunjukkan fluktuasi. Hal ini terlihat dari financing to deposits ratio (FDR) dan rasio non performing financing (NPF) yang memenuhi kriteria FDR dan rasio NPF bank jangkar. Dengan melihat rasio likuiditas kita dapat mengetahui kemampuan PT. BSMI dalam menyelesaikan kewajiban jangka pendeknya. 
Tabel. 7. Perkembangan FDR dan Rasio NPF PT. BSMI

Tahun 2004 s/d Tahun 2006 (Dalam Jutaan Rupiah)

\begin{tabular}{|l|l|r|r|r|}
\hline No. & Komponen & \multicolumn{1}{c|}{$\mathbf{2 0 0 4}$} & \multicolumn{1}{c|}{$\mathbf{2 0 0 5}$} & \multicolumn{1}{c|}{$\mathbf{2 0 0 6}$} \\
\hline 1 & Dana yang Diterima & 390.300 & 887.447 & 2.294 .248 \\
\hline 2 & Pembiayaan yang disalurkan & 271.085 & 523.149 & 2.110 .198 \\
\hline 3 & $\begin{array}{l}\text { Pembiayaan Bermasalah (KL, D, } \\
\text { M) }\end{array}$ & 8.505 & 2.916 & 28.932 \\
\hline 4 & FDR \% (2:1) & 69,46 & 59,97 & 91,98 \\
\hline 5 & NPF \% (3:2) & 3,14 & 0,56 & 1,35 \\
\hline
\end{tabular}

Ket: KL: Kulang Lancar, D: Diragukan, M: Macet.

Sumber: Direktori Perbankan Indonesia 2005 - Vol. 7, September 2006 dan http://www.bi.go.id, diolah.

Dari tabel 7, terlihat bahwa PT. BSMI mampu menjaga likuiditasnya, hal ini terlihat dari FDR dan rasio NPF yang berada di atas 50\% dan di bawah 3,5\%. FDR dan rasio NPF yang dihasilkan PT. BSMI selama tiga periode penelitian juga memenuhi kriteria FDR dan rasio NPF bank jangkar (FDR Min. 50\% dan NPF Maks. 5\%).

Fluktuasi FDR selama tiga periode penelitian tidak lepas dari angka pembiayaan yang disalurkan yang terus mengalami peningkatan, disamping dana yang diterima juga mengalami peningkatan. Pembiayaan yang disalurkan pada tahun 2005 meningkat sebesar 92,98\% dari tahun 2004 dan pada tahun 2006 kembali meningkat sangat tinggi sebesar 3003,36\% dari tahun 2005. FDR yang tinggi menunjukkan bahwa PT. BSMI memaksimalkan fungsi intermediasi. Tingginya FDR juga menunjukkan trust yang besar dari masyarakat yang menitipkan dananya di PT. BSMI. Dan komposisi dana titipan masyarakat tersebut didominasi oleh deposito bukan tabungan, hal ini menunjukkan bahwa yang berinteraksi dengan PT. BSMI adalah nasabah berdana besar yang menjadikan deposito sebagai sarana investasi mereka

Rasio NPF PT. BSMI mampu dijaga untuk tetap berada di bawah 5\% selama tiga periode penelitian, sesuai dengan kriteria rasio NPF bank jangkar. Keberhasiloan ini menunjukkan penerapan prudential banking dalam 
pembiayaan. Keberhasilan ini juga akibat dari proses akad atau perjanjian yang memperhatikan kebutuhan nasabah dan kebutuhan bank

\section{Faktor Solvabilitas}

Solvabilitas PT. BSMI selama tiga periode penelitian terus mengalami penurunan, hal ini terlihat dari capital adequacy ratio (CAR) dan rasio modal inti (RMI) yang selalu mengalami penurunan. CAR PT. BSMI mencapai kriteria CAR bank jangkar (Min. 12\%) hanya pada tahun 2004, tapi tidak untuk dua tahun berikutnya. Sedangkan RMI PT. BSMI menunjukkan penurunan tapi berada di atas kriteria RMI bank jangkar (Min. 6\%). Dengan menghitung rasio solvabiitas, kita dapat melihat kemampuan kecukupan modal PT. BSMI dalam mebndukung kegiatannya secara efisien.

Tabel. 8. Perkembangan CAR dan RMI PT. BSMI

Tahun 2004 s/d Tahun 2006 (Dalam Jutaan Rupiah)

\begin{tabular}{|l|l|r|r|r|}
\hline No. & Komponen & \multicolumn{1}{c|}{$\mathbf{2 0 0 4}$} & \multicolumn{1}{c|}{$\mathbf{2 0 0 5}$} & \multicolumn{1}{c|}{$\mathbf{2 0 0 6}$} \\
\hline 1 & Modal Inti & 59.568 & 65.216 & 135.992 \\
\hline 2 & Modal Pelengkap & 2.742 & 5.191 & 20.836 \\
\hline 3 & $\begin{array}{l}\text { Jumlah Modal } \\
(1+2)\end{array}$ & 62.310 & 70.407 & 156.828 \\
\hline 4 & Penyertaan & - & & - \\
\hline 5 & Total Modal (3-4) & 62.310 & 70.407 & 156.828 \\
\hline 6 & ATMR & 293.112 & 677.217 & 1.895 .984 \\
\hline 7 & CAR \% (5:6) & 21,26 & 10,40 & 8,27 \\
\hline 8 & RMI \% (1:6) & 20,30 & 9,63 & 7,17 \\
\hline
\end{tabular}

Sumber: Direktori Perbankan Indonesia 2005 - Vol. 7, September 2006 dan http://www.bi.go.id, diolah.

Dari tabel 8, terlihat CAR dan RMI PT. BSMI selalu mengalami penurunan. Penurunan tersebut adalah efek dari trust masyarakat yang sangat besar terlihat dari meningkatnya dana titipan masyarakat dan meningkatnya aktiva yang dimiliki PT. BSMI setiap tahunnya. Untuk mengantisipasi penurunan tersebut PT. BSMI perlu menambah modalnya. 
RMI PT. BSMI cukup bagus karena selalu berada di atas criteria RMI bank jangkar, akan tetapi CAR PT. BSMI yang perlu diperhatikan. Memang telah terjadi penambahan modal disetor sebesar 40 milar rupiah di tahun 2006 yang menguatkan RMI, namun tidak cukup membantu untuk menguatkan CARnya.

Untuk menguatkan CARnya, PT. BSMI harus melakukan penambahan modal. Salah satu cara yang dapat diambil dalam menambah modal adalah melalui penyertaan, atupun melalui penambahan modal pelengkap yang diizinkan sampai 100\% dari modal inti oleh bank Indonesia.

\section{Faktor Profitabilitas}

Profitabilitas PT. BSMI selama tiga periode penelitian mengalami fluktuasi. Hal ini terlihat dari rasio return on assets (ROA) PT. BSMI itu sendiri. Pada awal dan akhir periode penelitian rasio ROAnya berada di atas rasio ROA bank jangkar (Min. 1,5\%), Namun pada tahun 2005 rasio ROA PT. BSMI sangat rendah (0,36\%). Dengan menghitung rasio profitabilitas PT. BSMI, diha rapkan kita dapat mengetahui kemampuan PT. BSMI dalam menghasilkan laba.

Tabel. 9. Perkembangan Rasio ROA PT. BSMI

Tahun 2004 s/d Tahun 2006 (Dalam Jutaan Rupiah)

\begin{tabular}{|l|l|c|c|c|}
\hline No. & Komponen & $\mathbf{2 0 0 4}$ & $\mathbf{2 0 0 5}$ & $\mathbf{2 0 0 6}$ \\
\hline 1 & $\begin{array}{l}\text { Laba Sebelum } \\
\text { Pajak }\end{array}$ & 8.108 & 3.189 & 54.802 \\
\hline 2 & Total Aktiva & 400.871 & 896.910 & 2.352 .180 \\
\hline 3 & ROA \% (1:2) & 2 & 0,36 & 2,33 \\
\hline
\end{tabular}

Sumber: Direktori Perbankan Indonesia 2005 - Vol. 7, September 2006 dan http:/ / www.bi.go.id, diolah.

Dari tabel 9, terlihat rasio ROA PT. BSMI mengalami fluktuasi . Fluktuasi tersebut dikarenakan turunnya rasio ROA di tahun 2005 yang disebabkan oleh rendahnya laba sebelum pajak yang dihasilkan oleh PT. BSMI di tahun 2005. Hal ini juga adalah efek dari FDR yang hanya 59,97\%. 


\section{Kesimpulan}

Dari penelitian yang dilakukan diketahui bahwa bank umum syariah mempunyai potensi untuk menjadi bank jangkar. Potensi tersebut dilihat dari rasio keuangannya, dan yang paling berpotensi adalah PT. Bank Muamalat Indonesia. Selama tiga periode penelitian rasio keuangan PT. BMI lebih konsisten dibandingkan dua bank umum syariah lainnya, hal ini terlihat dari aspek-aspek rasio keuangan yang diteliti.

Bank umum syariah mampu menjaga likuiditasnya, hal ini terlihat dari financing to deposits ratio (FDR) yang di atas 50\% sesuai kriteria FDR bankjangkar. Dan rasio non performing financing (NPF) net yang berada di bawah kriteria NPF bank jangkar. Jadi dari aspek lukuiditas bank umum syariah memenuhi untuk menjadi bankjangkar.

Bank umum syariah kurang mampu menjaga solvabilitasnya, hanya PT. BMI yang mampu menjaga capital adequacy ratio (CAR)nya di atas $12 \%$ selama tiga perode penelitian. PT. BSM mencapai CAR di tahun 2006 saja, sedangkan PT. BSMI hanya mencapainya di tahun 2004. Adapun untuk rasio modal inti (RMI), semua bank umum syariah telah mampu mencapai dan menjaganya selama tiga periode.

Bank umum syariah kurang mampu menjaga profitabilitasnya. Rasio return on assets (ROA) OT. BMI masih menunjukkan fluktuasi demikian pula dengan PT. BSMI. Sedangkan rasio ROA PT. BSM menunjukkan penurunan. Yang paling baik menghasilkan rasio ROA adalah PT. BMI, sekalipun pada periode awal penelitian rasio ROAnya sedikit berada di bawah $(1,43 \%)$ rasio ROA bank jangkar. 


\section{DAFTAR PUSTAKA}

Abdullah, M. Faisal, 2004. Manajemen Perbankan. UMM Press, Malang.

Ali, Zulkarnain Muhammad. Saya Bangga dengan Almamater Tercinta. Dalam http:/ / uinjkt.ac.id/index.cfm? module=article.print\&recordid $=236 \&$ categoryid=125\&lang=in diakses tanggal 06-Juli-2007.

Apriliyanti, Dwi Nita, 2004. Analisis Rasio Keuangan Perbankan Sebagai Salah Satu Alat Untuk Menilai Perkembangan Kinerja Keuangan Bank Syariah. Skripsi Universitas Brawijaya Malang.

Arikunto, Suharsimi, 2002. Prosedur Penelitian Suatu Pendekatan Praktek. Edisi Revisi V, PT. Rineka Cipta, Jakarta.

Ascarya dan Yumanita, Diana, 2005. Bank Syari'ah (Gambaran Umum). Pusat Pendidikan dan Studi Kebanksentralan BI, Jakarta.

Bank Indonesia, Arsitektur Perbankan Indonesia, Maret 2006.

------------, Booklet Perbankan Indonesia 2006, Volume 3 No. 1, Maret 2006.

, Direktori Perbankan Indonesia 2005, Volume 7, September 2006.

, Statistik perbankan Indonesia, Volume 4 No. 9, Agustus 2006.

Brigham, Eugene F. dan Houston, Joel F. 2001. Manajemen Keuangan (Terj). Jilid I, Erlangga, Jakarta.

Bungin, H. M. Burhan, 2005. Metodologi Penelitian kuantitatif. Kencana, Jakarta.

Daruli, Efendi, 2003. Analisis Rasio Keuangan Sebagai Alat Untuk Menilai Tingkat Kesehatan dan Kinerja Perbankan Syariah: (Studi Kasus Pada PT. Ban Muamalat Indonesia). Skripsi Universitas Brawijaya Malang.

Deanto, 2003. Aplikasi Excel dalam Perencanaan, Pengendalian dan Analisis Kinerja Keuangan Bisnis. PT. Elex Media Komputindo, Jakarta.

Hidayat, Surahman, 1999. Mashoriful Islamiyah bi Andunisia wa Siyasatuha al istitsmaariyah (Muqaranah bil Mashoriful Islamiyah bi Misr). Desertasi Universitas al Azhar Kairo.

Husnan, Suad, 1998. Manajemen Keuangan Teori dan Penerapan. Buku 2, BPFE, yogjakarta. 
Indrianto, Nur dan Supomo, Bambang, 2002. Metodologi Penelitian Bisnis Untuk Akuntansi dan Manajemen. BPFE, Yogyakarta.

InfoBank, InfoBank Outlook 2006: Badai Belum Akan Berlalu.

Kartajaya, Hermawan dan Syula, Muhammad Syakir, 2006. Syari'ah Marketing. Mizan, Jakarta.

Kasmir, 2002. Dasar-Dasar Perbankan. PT. RajaGrafindo Persada, Jakarta.

Kompas, BI Minta Rencana Bisnis 2007. Edisi Kamis 14 Juli 2005.

Kuswadi, 2004. Cara Mudah Memahami Angka-Angka dan ManajemenKeuanganBagi Orang Awam. PT. Elex Media Komputindo, Jakarta.

Munawir, S. 1986. Analisis laporan Keuangan. Edisi 2, Liberty, Yogjakarta.

Retnadi, Djoko, 2006. Memilih Bank yang Sehat. PT. Elex Media Komputindo, Jakarta.

Sonhaji. 2003. Pengantar Akutansi 1, Bayu Media, Malang.

Suseno dan Abdullah, Piter. 2003. Sistem dan Kebijakan Perbankan di Indonesia. Pusat Pendidikan dan Studi Kebanksentralan BI, Jakarta.

Syamsuddin, Lukman. 2004. Manajemen Keuangan Perusahaan. PT. RajaGrafindo Persada, Jakarta.

Riana, Anida, 2004. Analisis Rasio CAMEL Sebagai Alat Untuk Menilai Tingkat Kesehatan Bank Syariah (Studi Kasus Pada PT. Bank Syariah Mandiri Pusat di Jakarta). Skripsi Universitas Brawijaya Malang.

Umar, Husein, 2005. Metode Penelitian untuk Skripsi dan Tesis Bisnis. PT. RajaGrafindo Persada, Jakarta.

www.bi.go.id diakses antara 13-05-2007 s/d 19-06-2007.

www.muamalatbank.com diakses pada 06-07-2007.

www.syariahmandiri.co.id diakses antara 13-05-2007 s/d 06-07-2007.

*) Achmad Zainuri, SE., Alumni Fakultas Ekonomi UIN Malang

**) Drs. Agus Sucipto, MM., Dosen Fakultas Ekonomi UIN Malang 